\title{
Peripheral ghrelin inhibits feed intake through hypothalamo-pituitary-adrenal axis-dependent mechanism in chicken*
}

\author{
E. Oclon ${ }^{1,3}$ and M. Pietras ${ }^{2}$ \\ ${ }^{1}$ University of Agriculture of Krakow, Department of Animal Physiology and Endocrinology \\ Al. Mickiewicza 24/28, 30-059 Kraków \\ ${ }^{2}$ The National Research Institute of Animal Production, \\ Department of Animal Nutrition and Feed Science \\ 32-083 Balice/Kraków
}

(Received 22 November 2010; revised version 3 March 2011; accepted 12 March 2011)

\begin{abstract}
It is known that centrally injected ghrelin is an anorexigenic peptide in chicken. Its activity is not mediated by NPY/AgRP - producing neurons but through the corticosterone releasing hormone (CRH) - expressing neurons in hypothalamus which activate the hypothalamo-pituitary-adrenal (HPA) axis inducing an increase in plasma corticosterone levels. However, controversial results of peripheral ghrelin effect on appetite have been reported. Thus, the influence of intraperitonealinjected ghrelin on the activity of the HPA axis in Cobb broiler chickens was examined. In addition, the effect of glucocorticoids antagonist (RU486) on the ghrelin activity was also investigated. The intraperitoneal co-injection of CRH-receptor antagonist, astressin, partially attenuated ghrelininduced anorexia and corticosterone release. Co-administration of RU486 significantly enhanced the inhibitory effect of ghrelin on feed intake in 7-day- old broiler chickens. These results indicate that the peripheral ghrelin - induced anorexia is caused by the stimulation of HPA axis in chickens.
\end{abstract}

KEY WORDS: ghrelin, HPA axis, CRH, glucocorticoids, receptor antagonist, feed intake, broiler chickens

\footnotetext{
* Supported by Grant for Scientific Research from the National Institute of Animal Production and in part by the Ministry of Science and Higher Education, Grant No. N 311-0250032/2215

${ }^{3}$ Corresponding author: e-mail: eoclon@ar.krakow.pl
} 


\section{INTRODUCTION}

The central and peripheral regulatory mechanisms in energy homeostasis, including feed intake and energy expenditure, in avian species have been recently extensively studied (Richards, 2003; Richards and McMurtry, 2010). Many of neural and endocrine mechanisms identified in mammals as involving in regulation feed intake also have this function in birds. For instance, neuropeptide Y (NPY) and agouti-related protein (AgRP) are mediators of many appetite-stimulatory peptides in central nervous system (CNS) in both groups (Zhou et al., 2005). However, there are some responses such as ghrelin that are unique to avian.

Ghrelin is an endogenous ligand of the growth hormone secretagagogue receptor (GHS-R) that was first purified from rat stomach and named for its growth hormone (GH) releasing activity (Kojima et al., 1999). Ghrelin is predominantly produced in the mucosal layer of stomach, although its mRNA has been detected in central nervous system (hypothalamus), pituitary and peripheral (intestine, pancreas, kidney, lung, placenta) tissues as well as in the immune system (Korbonits et al., 2004). It is known that the principal effects of ghrelin is stimulating GH - release and regulating energy homeostasis (Kojima and Kangawa, 2005). In mammals, ghrelin stimulates feed intake and its orexigenic effect is mediated by NPY/AgRP - neurons projecting from arcuate nucleus (ARC) to paraventricular nucleus (PVN) in the hypothalamus (Wang et al., 2001).

It was shown that avian ghrelin elevates GH level in dose and time dependent manner (Ahmed and Harvey, 2002; Baudet and Harvey, 2003). However, the main difference in ghrelin function between birds and mammals relates its role in the regulation of feed intake. There have been reports that centrally injected ghrelin strongly inhibit feed intake in neonatal chicks (Saito et al., 2005; Khan et al., 2006). Saito et al. (2005) suggested that the inhibitory effect of central ghrelin on feeding is caused by activating the corticotropin releasing hormone (CRH) - producing neurons. Intracerebroventricular (icv) administration of ghrelin stimulated corticosterone release in a dose- and time-dependent manner (Shousha et al., 2005). Additionally, this effect was completely blocked by CRH receptor antagonist (astressin) injection what suggests that central ghrelin may interact with HPA axis (Saito et al., 2005). In poultry, the impact of ghrelin administered peripherally produced controversial results from having no effects (Kaiya et al., 2007) to inhibiting (Geelissen et al., 2006) or stimulating (Shousha et al., 2005) feed intake.

Thus, in the present study, it was examined whether exogenously (intraperitoneally; ip) administered ghrelin may induce anorexia by activating the HPA axis. 


\section{MATERIAL AND METHODS}

\section{Animals}

Seven-day-old commercials Cobb broilers $(n=222)$ were purchased from the local hatchery (Brzesko, Poland). They had free access to water and chicken starter diet. Temperature was maintained at $32 \pm 2^{\circ} \mathrm{C}$. All experimental procedures followed the guidelines for the care and use of experimental animal at National Institute of Animal Production.

Birds were placed in individual cages $24 \mathrm{~h}$ before the experiments. Before each experiment chicken were weighed and distributed into experimental groups so that the average body weight (BW) was as uniform as possible between treatment groups $(170.37 \pm 13.8 \mathrm{~g})$.

\section{Peptides}

Chicken ghrelin was purchased from Phoenix Pharmaceuticals, Inc. (CA, USA). CRH receptor antagonist ([D-Phe $\left.{ }^{12}, \mathrm{Nle}^{21,38}, \mathrm{Glu}^{30}, \mathrm{Lys}^{33}\right]$ - Corticotropin Releasing Hormone fragment 12-41; astressin) and glucocorticoids receptor antagonist (1 $\beta$-(4-Dimethyl amino) phenyl-17 $\beta$-hydroxy -17 -(1- propynyl)estra4,9-dien-3- one; RU 486/Mifepristone) were purchased from Sigma-Aldrich Co (USA). All peptides were dissolved in $0.85 \%$ saline containing $0.1 \%$ Evans Blue dye (Sigma-Aldrich Co, USA) and injected ip in a volume $20 \mu \mathrm{l}$ after $3 \mathrm{~h}$ of fasting in order to stimulate and synchronize feed intake.

\section{Experimental design}

Four experiments were conducted to determine the effect of peripherally injected ghrelin on feed intake by chicken. Except for experiment 1 described below, the remaining experiments involved the measurement of feed intake and/or plasma corticosterone levels. The quantity of feed was determined after 30, 60 and 120 min after the single administration of ghrelin by measuring the disappearance of diet from the pre-weighed feeder with an accuracy of $0.01 \mathrm{~g}$. Plasma corticosterone was determined at 30,60 and 120 min after ip injection of ghrelin.

In experiment 1 , chicken $(\mathrm{n}=24)$ were divided into two groups: control fed $a d$ libitum and experimentally fasted for $24 \mathrm{~h}$. During the feed deprivation periods, the chicken had free access to water.

In experiment 2 , chicken $(n=54)$ were divided into three groups, and either chicken ghrelin ( 0.5 or $2 \mathrm{nmol} / 100 \mathrm{BW}$ ) or saline (control) was ip administrated. 
Based on the result from experiment 2, the dose of chicken ghrelin $0.5 \mathrm{nmol} / 100 \mathrm{~g}$ BW was used in experiments 3 and 4 . In experiment 3, chicken $(\mathrm{n}=72)$ were divided into four groups and subjected to the following ip injections: saline (control), chicken ghrelin $(0.5 \mathrm{nmol} / 100 \mathrm{~g} \mathrm{BW})$, astressin $(6 \mathrm{nmol} / \mathrm{chicken})$ and chicken ghrelin with astressin $(0.5 \mathrm{nmol} / 100 \mathrm{~g} \mathrm{BW}$ and $6 \mathrm{nmol} /$ chicken).

In Experiment 4, chicken $(\mathrm{n}=72)$ were divided into four groups: saline (control), chicken ghrelin (0.5 nmol/100 g BW), RU $486(50 \mathrm{mg} / \mathrm{kg} \mathrm{BW})$ and chicken ghrelin with RU 486 (0.5 nmol/100 g BW and $50 \mathrm{mg} / \mathrm{kg} \mathrm{BW})$.

At the end of experiments, the chicken were decapitated. Blood samples and tissues (pituitary, proventriculus, adrenal glands) were collected and stored at $-80^{\circ} \mathrm{C}$ for further RNA isolation and/or ghrelin and corticosterone RIA detection. Tissues were weighed, and homogenized in $50 \mathrm{mMTris}-\mathrm{HCl}$ (pH 7.4). Homogenates were boiled for $20 \mathrm{~min}$ to inactivate intrinsic proteases and centrifuged for $30 \mathrm{~min}$ at $10,000 \mathrm{~g}$. The supernatants were collected and lyophilized. The appropriate RIA measured total ghrelin after reconstitution in $10 \mathrm{mM}$ phosphate buffer ( $\mathrm{pH} 6.5)$.

Ghrelin and corticosterone concentrations were measured using a commercial RIA kits (Ghrelin TOTAL Linco, USA and Corticosterone RIA KIT MP Biomedicals, USA) according to the manufacturer's protocol.

\section{RNA extraction and $c D N A$ synthesis}

Total RNA was extracted from chicken proventriculus (experiment 1) using the Trizol Reagent (Applied Biosystems, USA) according to the method given by Chomczynski and Sacchi (1987). Concentration and purity of the RNA samples were determined by UV spectroscopy at $260 / 280 \mathrm{~nm}$, and integrity was confirmed by electrophoresis through $1 \%$ agarose gels stained with ethidium bromide. First strand cDNA was transcribed from $1 \mu \mathrm{g}$ RNA with MultiScribe Reverse Transcriptase (50 U/ $\mu$ l, Applied Biosystems, USA) using random primers at $25^{\circ} \mathrm{C}$ for $10 \mathrm{~min}$ followed by $37^{\circ} \mathrm{C}$ for $120 \mathrm{~min}$ and $85^{\circ} \mathrm{C}$ for $5 \mathrm{~s}$ (High Capacity cDNA Reverse Trancription Kit, Applied Biosystems, USA). The cDNA was reconstituted in $50 \mu \mathrm{l}$ of sterilized water and $200 \mathrm{ng}$ of the cDNA solution was used as a template.

\section{Quantitative PCR}

Quantitative PCR analysis was performed using the 7500 Real-Time PCR System (Applied Biosystems, USA) with the Universal Master Mix and TaqMan chemistry (Applied Biosystems, USA).

The sequences of $g h r l$ primers and the TaqMan fluorogenic probe are given in Table 1. The amplicon size was $67 \mathrm{bz}$. Amplification and detection were 
Table 1. Sequences of starters and probe

\begin{tabular}{lcc}
\hline Gene & Starter sequences (5'-3') & Probe (5'-3') \\
\hline Ghrl & F: GCTCTAGTTTTTTAAGCCCCACATAT & CATACAGCAACAAAAGG \\
\hline
\end{tabular}

carried out in optical-grade 96-well plates with an initial step of $50^{\circ} \mathrm{C}$ for $2 \mathrm{~min}$, which is the required optimal AmpErase UNG enzyme activity, and then at $95^{\circ} \mathrm{C}$ for $10 \mathrm{~min}$, to activate the AmpliTaq Gold DNA polymerase and to deactivate the AmpErase UNG enzyme, followed by 40 cycles of $95^{\circ} \mathrm{C}$ for $15 \mathrm{~s}$ and $60^{\circ} \mathrm{C}$ for $1 \mathrm{~min}$. Data obtained for ghrelin were compared with data obtained from amplification of reference gene 18sRNA (Applied Biosystems, USA). Data were calculated as $2^{-\Delta \Delta \mathrm{Ct}}$ where $\Delta \mathrm{C}_{\mathrm{T}}=\mathrm{C}_{\mathrm{T} \text { gene of ghrelin }}-\mathrm{C}_{\mathrm{T}}{ }_{18 \mathrm{sRNA}}$ and $\Delta \Delta \mathrm{C}_{\mathrm{T}}$ is the change between the $\Delta \mathrm{C}_{\mathrm{T}}$ for each sample and the control group. Samples in which no amplified product could be detected by cycle 40 were considered not to express the gene being assayed.

\section{Statistical analysis}

Data from experiment 1 was analysed by the Student's t-test. Data from experiments 2-4 were analysed by the Tukey-Kramer test. All statistics was performed using the commercial package StatViev (SAS Institute).

\section{RESULTS}

In experiment 1, the effect of fasting on ghrelin expression and concentration in oneweek-old chickens were examined. Twenty four $\mathrm{h}$ of fasting significantly increased ghrelin mRNA levels in proventriculus (from $0.0620 \pm 0.007$ ghrelin/18sRNA to $0.110 \pm 0.012$ ghrelin/18sRNA Mrna; $\mathrm{P}<0.01$; Figure 1). Furthermore, ghrelin

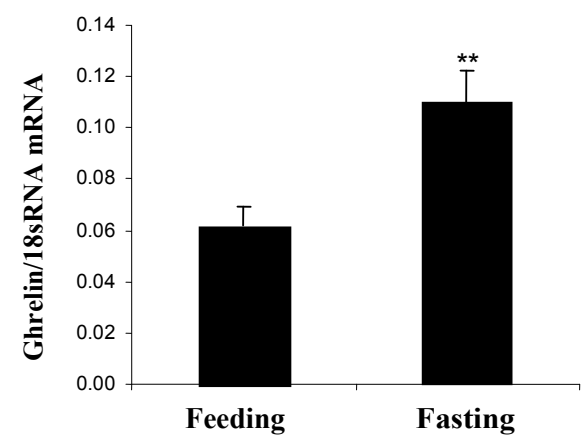

Figure 1. Effect of $24 \mathrm{~h}$ fasting on proventriculus ghrelin mRNA levels. Data are means \pm SEM of 12 chicken in each groups. *significant with respect to feeding $(\mathrm{P}<0.01)$ 
peptide concentration in all experimental tissues (proventriculus; $\mathrm{P}<0.01$; pituitary, adrenal glands; $\mathrm{P}<0.05$ ) were increased significantly following $24 \mathrm{~h}$ of feed deprivation (Figures 2 a-d). The date indicated that plasma ghrelin levels were also significantly $(\mathrm{P}<0.01)$ increased by fasting (Figure $2 b)$.
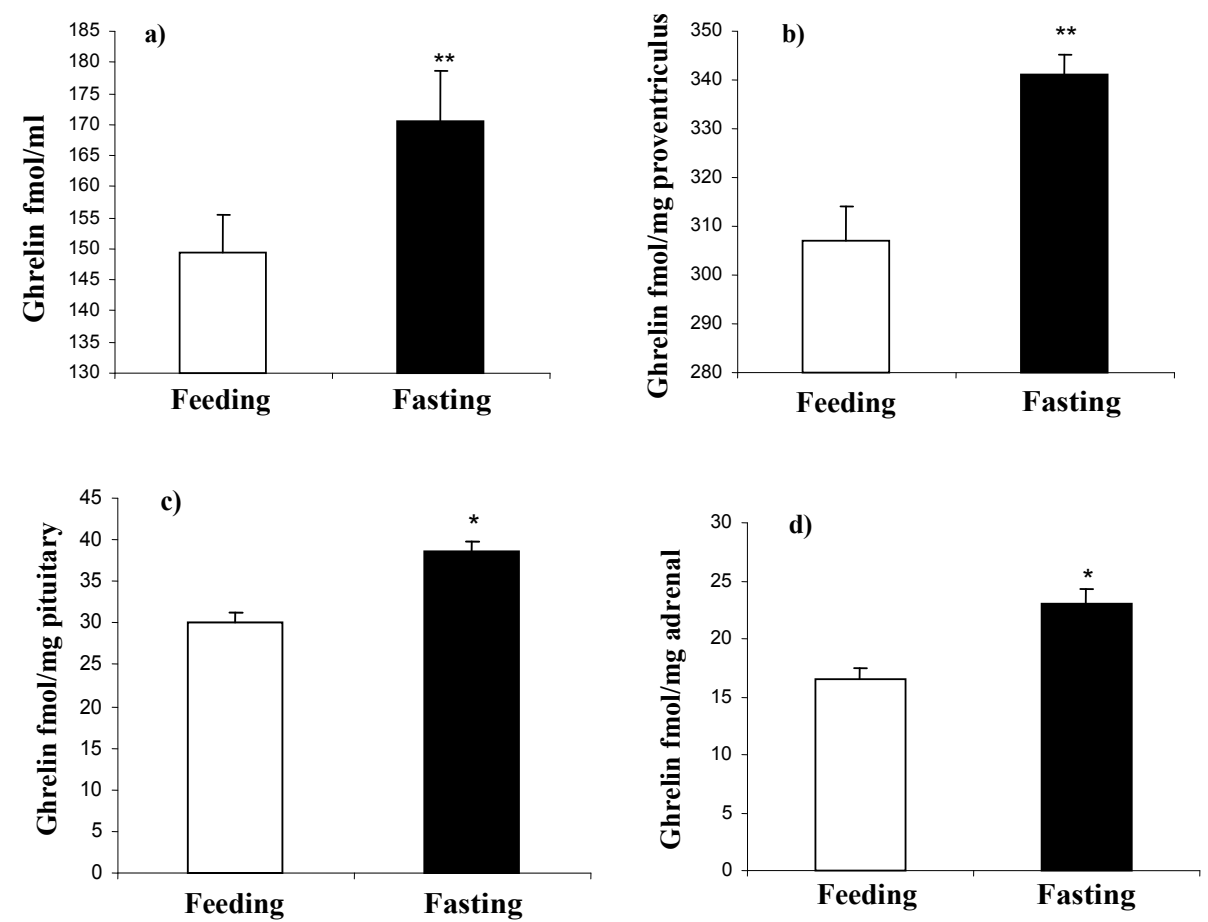

Figure 2. Effect of $24 \mathrm{~h}$ fasting on ghrelin concentration in (a) plasma, (b) proventriculus, (c) pituitary and (d) adrenal glands. Data are means \pm SEM of 12 chicken in each groups. **Significant with respect to feeding $(\mathrm{P}<0.01)$ and $*(\mathrm{P}<0.05)$

In experiment 2 , the results indicated that the ip-injected ghrelin strongly inhibited feed intake in dose- and time-dependent manner $(\mathrm{P}<0.05$; Figure 3$)$.

Feed intake was already suppressed after $30 \mathrm{~min}$ and remained decreased until $2 \mathrm{~h}$ after injection of both ghrelin doses. In addition, peripheral ghrelin-elicited corticosterone release was observed during $2 \mathrm{~h}$ of the experiment in dose- and time-dependent manner $(\mathrm{P}<0.05$; Figure 4$)$. 
$\square$ Control $\square 0.5 \mathrm{nmol} \square 2 \mathrm{nmol}$
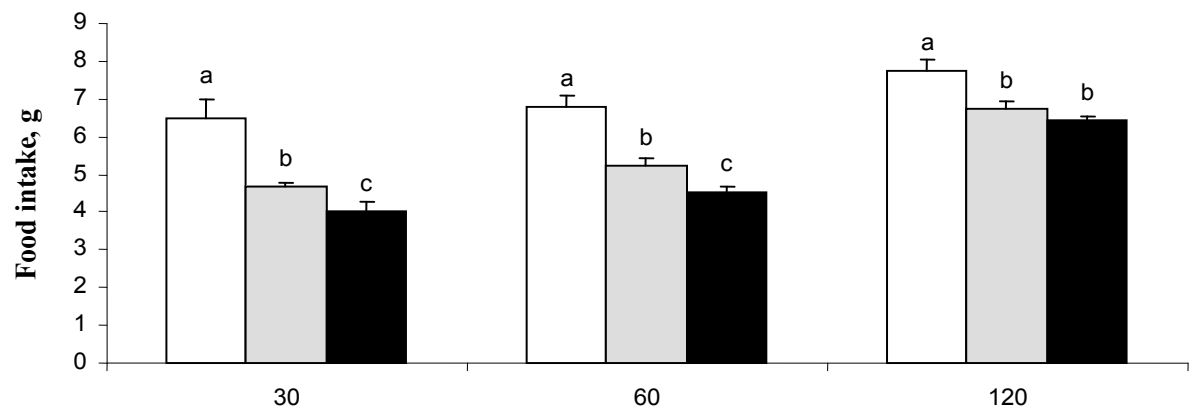

Time after injection, $\mathrm{min}$

Figure 3. Effect of peripheral administration of ghrelin on feed intake ( $\mathrm{n}=54)$. Data are means \pm SEM. Groups with different letters are significantly different $(\mathrm{P}<0.05)$ at each time point

$\square$ Control $\square 0.5 \mathrm{nmol} \square 2 \mathrm{nmol}$

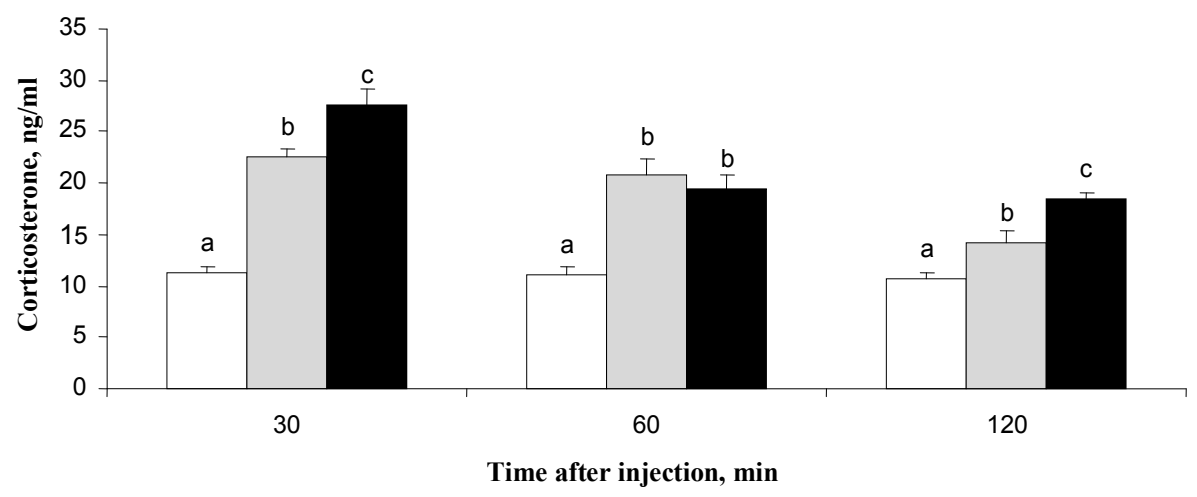

Figure 4. Effect of peripheral administration of ghrelin on plasma corticosterone levels $(n=54)$. Data are means \pm SEM. Groups with different letters are significantly different $(\mathrm{P}<0.05)$ at each time point

In experiment 3 , the effect of ip-administrated chicken ghrelin and/or antagonists of CRF receptors (astressin) and glucocorticoids antagonists on feed intake and plasma corticosterone levels were investigated. Astressin in combination with ghrelin attenuated the inhibitory effect of ghrelin on feed intake 60 min after ip-injection $(\mathrm{P}<0.05$; Figure 5). The results indicated that co-administration of CRF-receptor antagonist with chicken ghrelin partially reversed ghrelin-induced corticosterone release. Astressin alone decreased plasma 
$\square$ Control $\square$ Ghrelin $\square$ Astressin $\square$ Astressin+Ghrelin

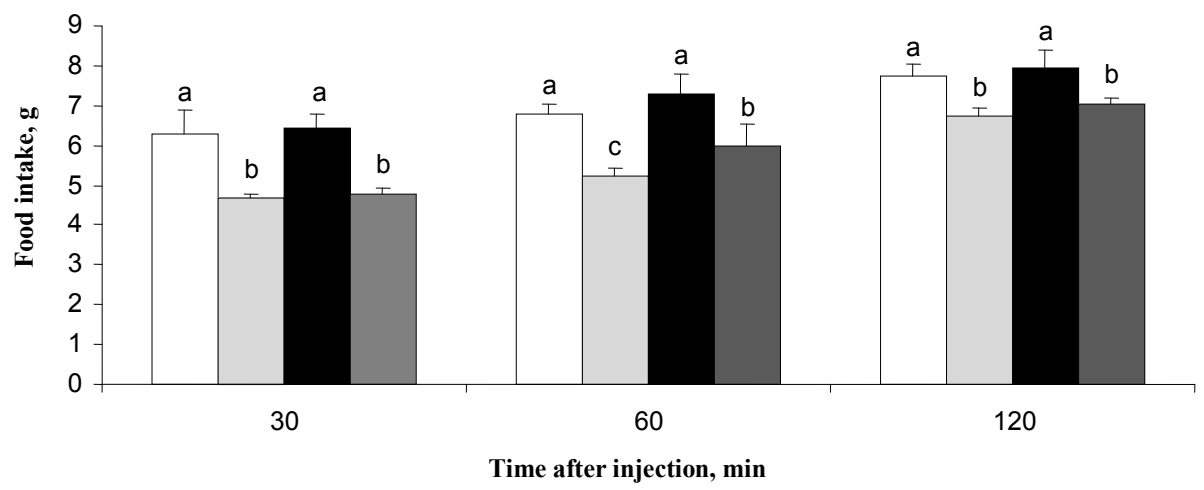

Figure 5. Effect of peripheral administration of ghrelin, astressin and their combination on feed intake $(n=72)$. Data are means \pm SEM. Groups with different letters are significantly different $(\mathrm{P}<0.05)$ at each time point

corticosterone levels at $60 \mathrm{~min}$ from $10.903 \pm 0.500 \mathrm{ng} / \mathrm{ml}$ to $8.604 \pm 0.313 \mathrm{ng} / \mathrm{ml}$ $(\mathrm{P}<0.05$; Figure 6). Furthermore, ip-injected astressin declined plasma ghrelin levels one hour after treatment $(\mathrm{P}<0.05$; Figure 7$)$.

\section{$\square$ Control $\square$ Ghrelin $\square$ Astressin $\square$ Astressin+Ghrelin}

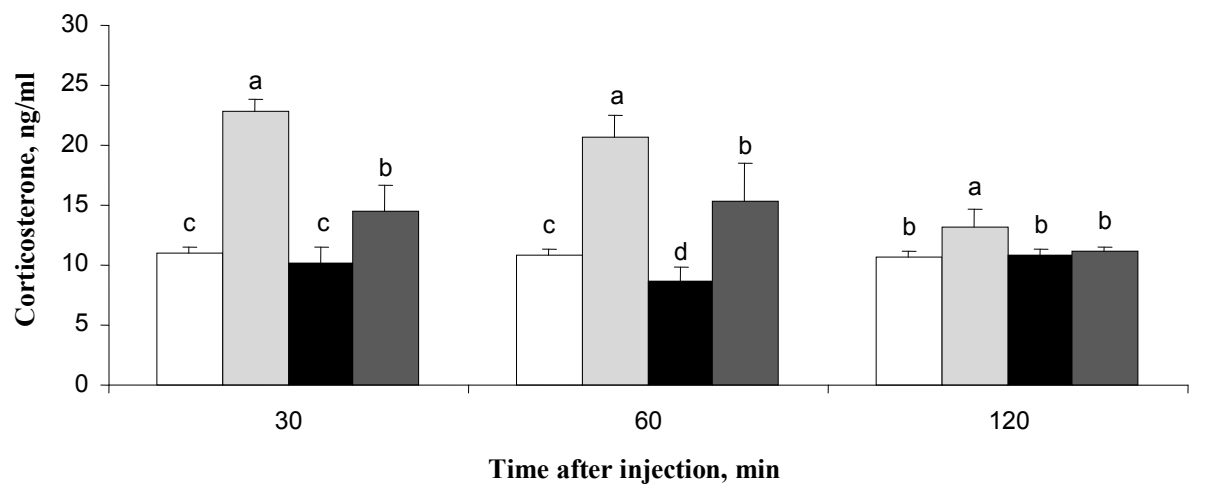

Figure 6. Effect of peripheral administration of ghrelin, astressin and their combination on plasma corticosterone levels $(\mathrm{n}=72)$. Data are means \pm SEM. Groups with different letters are significantly different $(\mathrm{P}<0.05)$ at each time point 
$\square$ Control $\square$ Astressin

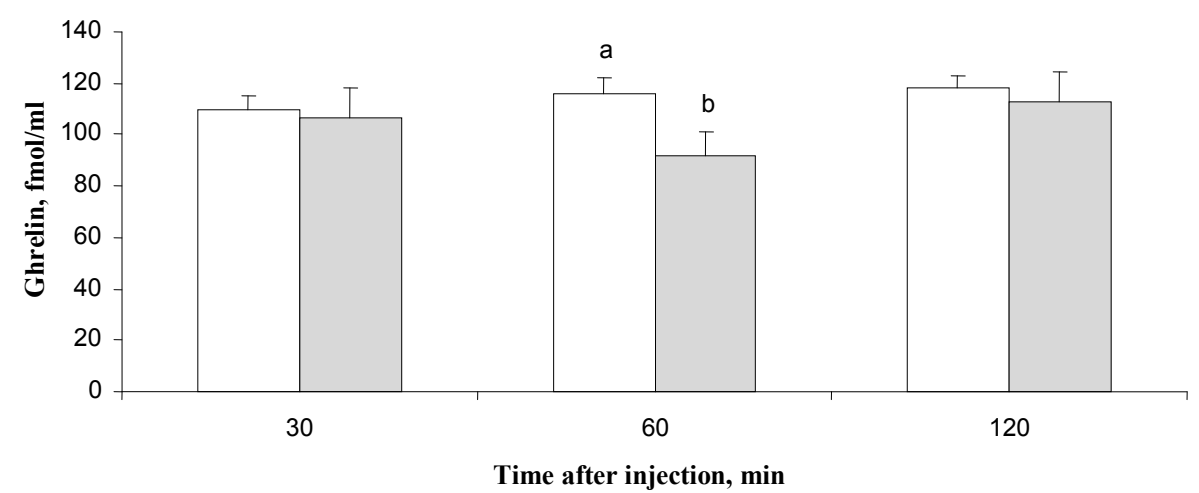

Figure 7. Effect of peripheral administration of astressin on plasma ghrelin levels $(n=36)$. Data are means \pm SEM. Groups with different letters are significantly different $(\mathrm{P}<0.05)$ at each time point

The data indicated that the peripheral administration of glucocorticoids antagonist (RU486) significantly inhibited feed intake during one $\mathrm{h}$ after injection $(\mathrm{P}<0.05$; Figure 8). Additionally, the co-injection of RU486 with ghrelin strongly enhanced inhibitory effect of ghrelin on feed intake at least 60 min after treatment $(\mathrm{P}<0.05$; Figure 8). RU486 alone declined plasma corticosterone levels during one hour of the experiment. The glucocorticoids antagonist in combination with ghrelin attenuated ghrelin-induced corticosterone

$\square$ Control $\square$ Ghrelin $\square$ RU486 $\square$ RU486+Ghrelin

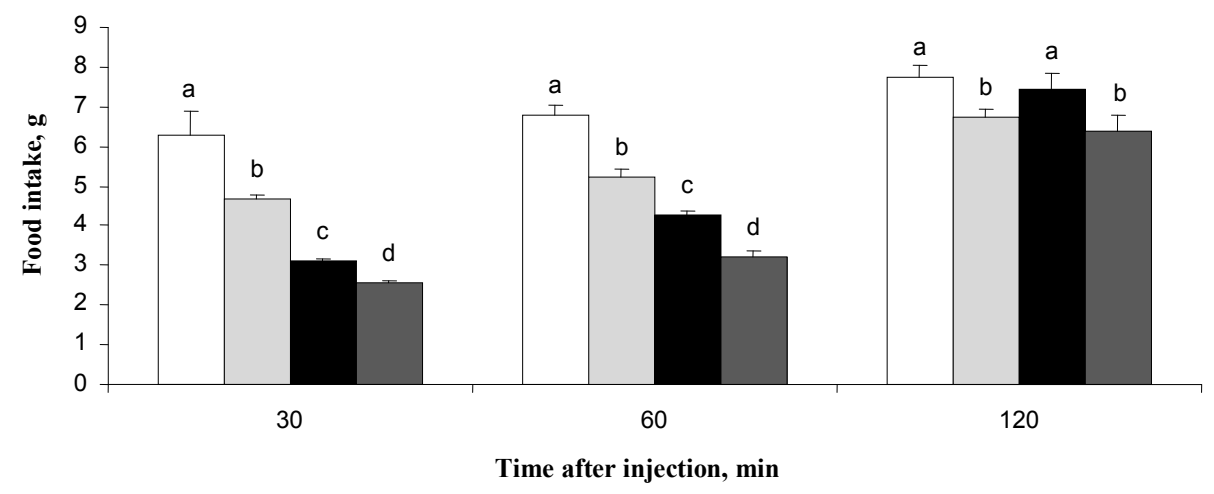

Figure 8. Effect of peripheral administration of ghrelin, RU486 and their combination on feed intake $(\mathrm{n}=72)$. Data are means \pm SEM. Groups with different letters are significantly different $(\mathrm{P}<0.05)$ at each time point 
release one hour after injection $(\mathrm{P}<0.05$; Figure 9). Furthermore, ip-injected RU486 did not change plasma ghrelin level ( $\mathrm{P}<0.05$; Figure 10).

\section{$\square$ Control $\square$ Ghrelin $\square$ RU486 $\square$ RU486+Ghrelin}

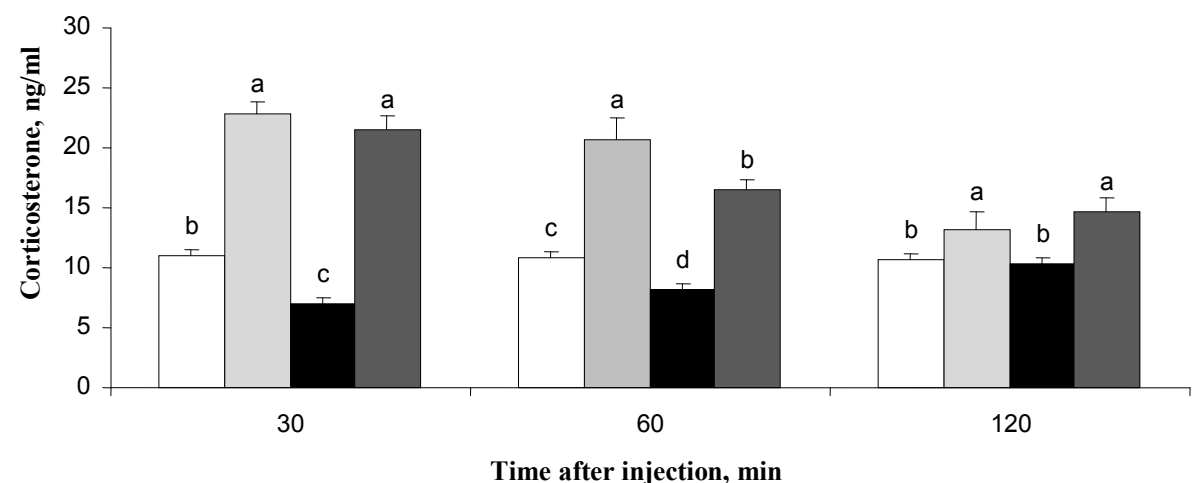

Figure 9. Effect of peripheral administration of ghrelin, RU486 and their combination on plasma corticosterone levels $(n=72)$. Data are means \pm SEM. Groups with different letters are significantly different $(\mathrm{P}<0.05)$ at each time point

$\square$ Control $\square$ RU486

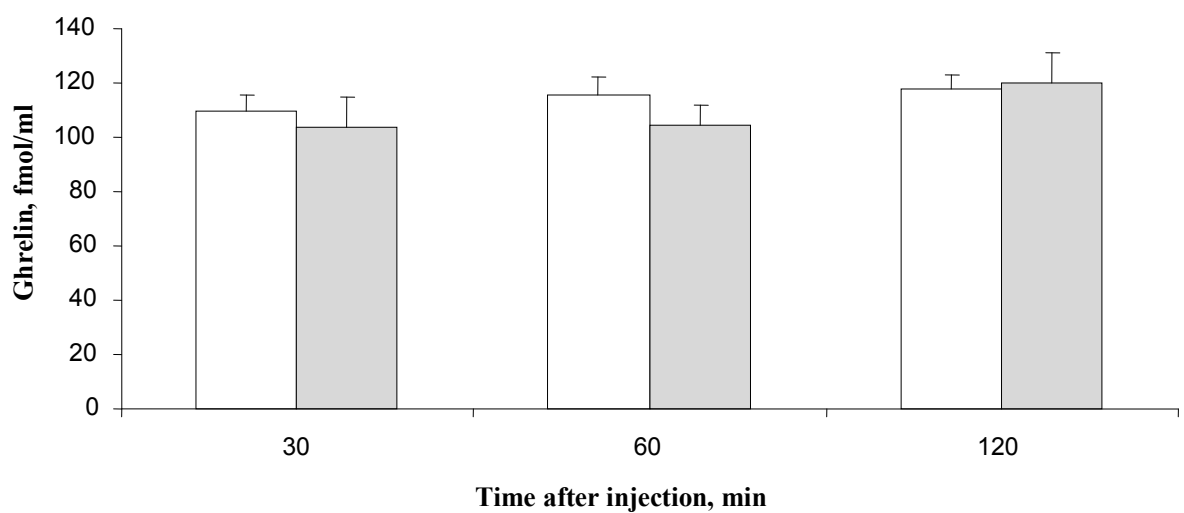

Figure 10. Effect of peripheral administration of RU486 on plasma ghrelin levels (n=36). Data are means \pm SEM

\section{DISCUSSION}

Ghrelin expression and secretion are associated with feeding status. Toshinai et al. (2001) reported that plasma ghrelin levels increased during 12-h fasting 
and returned to the basal concentration after re-feeding. The current study demonstrated an increase in ghrelin mRNA expression and peptide concentration in proventriculus after $24 \mathrm{~h}$ fasting similar to the previous results reported by Geelissen et al. (2006). Furthermore, we observed an increase in ghrelin concentration in homogenates from pituitary and adrenal glands. The obtained results support the idea that ghrelin acts either directly on adrenal glands or indirectly through CRF - expressing neurons.

It is known that ghrelin is an anorexigenic peptide in chicken when injected centrally (Kaiya et al., 2007). However, controversial effects of peripheral ghrelin on appetite have been reported. Intravenous injection of chicken ghrelin ( $1 \mathrm{nmol} / 100 \mathrm{~g} \mathrm{BW}$ ) inhibited feed intake during the first $\mathrm{h}$ after administration in 7-day-old broiler chickens (Geelissen et al., 2006), while ip injection of $0.6 \mathrm{nmol} / 100 \mathrm{~g} \mathrm{BW}$ of ghrelin does not change feed intake in 8-day-old Leghorn chickens during $2 \mathrm{~h}$ of experiment (Kaiya et al., 2007). Moreover, Shousha et al. (2005) reported that low doses of ghrelin injected ip $(0.4$ and $0.8 \mathrm{nmol} / 100 \mathrm{~g}$ BW) stimulated appetite in adult Japanese quail. Although, the present results show that ip injection of chicken ghrelin with both high and low doses (2 and $0.5 \mathrm{nmol} / 100 \mathrm{~g} \mathrm{BW}$ ) significantly suppressed feed intake throughout the experimental period (from 30 to $120 \mathrm{~min}$ after administration). This difference may be due to the dissimilar effect of ghrelin on appetite between egg- laying type and meat- type chickens (Nie et al., 2004; Richards, 2003).

Saito et al. (2005) were first to report that the activity of chicken ghrelin is not mediated by NPY/AgRP-producing neurons but through the CRH -expressing neurons in hypothalamus which cause the inhibition of the appetite and activate the HPA axis inducing an increase in plasma corticosterone levels. Similarly to the previous study, in which intravenous injected ghrelin stimulated corticosterone release (Kaiya et al., 2002), we observed that ip ghrelin administration significantly increase plasma corticosterone concentration in 7-day-old chickens and the effect is distinctly time and dose dependent. Moreover, the ghrelin-elicited corticosterone release and ghrelin-induced anorexia were partially attenuated by the co-injection of astressin, CRH receptors antagonist, during at least one $\mathrm{h}$ after administration. $\mathrm{CRH}$ and receptors that were initially characterized in the brain (where they inhibit feed intake) have recently been shown to be widely expressed in peripheral tissues, including the gastrointestinal tract. In mammals, researchers recently reported that des-acyl ghrelin is also a biologically active peptide which inhibits feed intake by CRH type 2 receptors (Chen et al., 2005). The effect was not altered by capsaicin treatment which indicate that peripheral des-acyl ghrelin may induce anorexigenic function by direct activation of brain receptor by crossing the blood-brain barrier but not by the activation of vagal afferent pathways (Chen et al., 2005). Although little is 
known about des-ghrelin in birds, Saito et al. (2002) reported that icv injection of des-ghrelin did not change feed intake in neonatal chicks. However, in the present study, we reported that activity of ghrelin was restricted after peripheral blocking of CRH receptors in 7-day-old chickens.

In addition, we also investigated the influence of injection the glucocorticoids receptor antagonist (RU 486) on ghrelin activity. The administration of RU486 strongly inhibited feed intake throughout the experimental period. The glucocorticoids receptor antagonist in combination with chicken ghrelin strongly enhanced the inhibitory effect of ghrelin on appetite during at least $2 \mathrm{~h}$ after treatment. The result may suggest that the blocking corticosterone effect by RU 486 caused an increase CRH concentration which provided to improve ghrelin-induced anorexia. The HPA axis plays a critical role in the regulation of energy balance. An increase of feed intake is associated with glucocorticoid excess. Inversely, removal of glucocorticoid by adrenalectomy (ADX) reduces hyperphagia and body weight in rodents. In mammals it has been previously reported that administration of synthetic glucocorticoid (dexamethasone $200 \mu \mathrm{g} /$ day) increased GHS-R mRNA levels in adrenalectomized rats. Furthermore, an addition of dexamethasone to pituitary cell cultures increased GHS-R mRNA levels in a dose- and time-dependent manner while supplementation of the transcriptional inhibitor (actinomycin A) completely blocked the stimulatory effect of glucocorticoids in rat (Tamura et al., 2000). These findings suggest that the suppression of corticosterone release may cause a decrease in expression of GHS-R and in consequence the limitation in ghrelin activity. Little is known about the influence of corticosterone on stimulating GHS-R gene transcription in chicken. The result of the present study indicate that the antagonist of glucocorticoid in combination with chicken ghrelin partially reversed stimulatory effect of ghrelin on corticosterone release at $60 \mathrm{~min}$ after injection. It is possible that similar to the mechanism in mammals, in which the lowered level of glucocorticoid is a restricted factor of growth hormone secretagagogue receptor (GHS-R) mRNA expression also in chickens. This hypothesis needs to be examined in future.

In conclusion, our data indicate that appetite - suppressive action of peripheral ghrelin is associated with activity of HPA axis in chickens.

\section{REFERENCES}

Ahmed S., Harvey S., 2002. Ghrelin: a hypothalamic GH - releasing factor in domestic fowl (Gallus domesticus). J. Endocrinol. 172, 117-125

Baudet M.L., Harvey S., 2003. Ghrelin - induced GH secretion in domestic fowl in vivo and $\mathrm{n}$ vitro. J. Endocrinol. 179, 97-105 
Chen C.Y., Inui A., Asakawa A., Fujino K., Kato I., Chen C.C., Ueno N., Fujimiya M., 2005. Des - acylghrelin acts by CRF type 2 receptors to disrupt fasted stomach motility in conscious rats. Gastroenterology 129, 8-25

Chomczynski P., Sacchi N., 1987. Single-step method of RNA isolation by acid guanidinium thiocyanate-phenol-chloroform extraction. Anal. Biochem. 162, 156-159

Geelissen S.M., Swennen Q., Geyten S.V., Kühn E.R., Kaiya H., Kangawa K., Decuypere E., Buyse J., Darras V.M.. 2006. Peripheral ghrelin reduces food intake and respiratory quotient in chicken. Domest. Anim. Endocrinol. 30, 108-116

Kaiya H., van der Geyten S., Kojima M., Hosoda H., Kitajima Y., Matsumoto M., Geelissen S., Darras V.M. Kangawa K., 2002. Chicken ghrelin: purification cDNA cloning and biological activity. Endocrinology 143, 3454-3463

Kaiya H., Saito E.S., Tachibana T., Furuse M., Kangawa K., 2007. Changes in ghrelin levels of plasma and proventriculus and ghrelin mRNA of proventriculus in fasted and refed layer chicks. Domest. Anim. Endocrinol. 32, 447-259

Khan M.S.I., Dodo K., Yahata K., Nishimoto S., Ueda H., Taneike T., Kitazawa T., Hosaka Y., Bungo T., 2006. Intracerebroventricular administration of growth hormone releasing peptide -6 (GHRP - 6) inhibits food intake, but not food retention of crop and stomach in neonatal chicks. J. Poultry Sci. 43, 35-40

Kojima M., Hosoda H., Date Y., Nakazato M., Matuso H., Kangawa K., 1999. Ghrelin is a growth hormone releasing acylated peptide from stomach. Nature 402, 656-660

Kojima M., Kangawa K., 2005. Ghrelin: structure and function. Physiol. Rev. 85, 495-522

Korbonits M., Goldstone A.P., Gueorguiev M., Grossman A.B., 2004. Ghrelin--a hormone with multiple functions. Front. Neuroendocrinol. 25, 27-68

Nie Q., Zeng H., Lei M., Oshag N.A., Fang M., Sun B., Yang G., Zhang X., 2004. Genomic organisation of the chicken ghrelin gene and its single nucleotide polymorphisms detected by denaturing high-performance liquid chromatography. Brit. Poultry Sci. 45, 611-618

Richards M.P., 2003. Genetic regulation of feed intake and energy balance in poultry. Poultry Sci. 82, 907-916

Richards M.P., McMurtry J.P., 2010. The avian proghrelin system. Int. J. Peptides 10, 401-414

Saito E.S., Kaiya H., Tachibana T., Tomonaga S., Denbow D.M., Kangawa K., Furuse M., 2005. Inhibitory effect of ghrelin on food intake is mediated by the corticotropin - releasing factor system in neoatal chicks. Regul. Peptides 125, 201-208

Saito E.S., Takagi T., Nakanishi T., Sashihara K., Furuse M., 2002. Ghrelin activates behavior of neonatal chicks in a short period of post - intracerebroventricular injection. J. Appl. Anim. Res. $22,33-41$

Shousha S., Nakahara K., Kojima M., Miyazato M., Hosoda H., Kangawa K., Murakami N., 2005. Different effects of peripheral and central ghrelin on regulation of food intake in the Japanese quail. Gen. Comp. Endocrinol. 141, 178-183

Tamura H., Kamegai J., Sugihara H., Kineman R.D., Frohman L.A., Wakabayashi I., 2000. Glucocorticoids regulate pituitary growth hormone secretagogue receptor gene expression. J. Neuroendocrinol. 12, 481-485

Toshinai K., Mondal M.S., Nakazato M., Date Y., Murakami N., Kojima M., Kangawa K., Matsukura S., 2001. Upregulation of ghrelin expression in the stomach upon fasting, insulin - induced hypoglycemia, and leptin administration. Biochem. Biophys. Res. Commun. 281, 1220-1225

Wang X., Day J.R., Vasilatos-Younken R., 2001. The distribution of neuropeptide Y gene expression in the chicken brain. Mol. Cell. Endocrinol. 174, 129-136

Zhou W., Murakami M., Hasegawa S., Yoshizawa F., Sugahara K., 2005. Neuropeptide Y content in the hypothalamic paraventricular nucleus responds to fasting and refeeding in broiler chickens. Comp. Biochem. Physiol. Pty. A 141, 146-152 